reassurance did not change participants initial impressions of acceptability.

Conclusion Conducting a human challenge study in pregnancy would be acceptable to some pregnant women and may offer a means to investigate the specific environment that surrounds commensalisation of neonates. Furthermore, this may offer new avenues to explore vaccine development for the prevention of neonatal infection. While participants would want the maximum amount of information available before considering whether to participate, initial aversion to this methodology it is unlikely to be changed.

\section{G603(P) NEONATAL CHIKUNGUNYA: AN INDIAN PERSPECTIVE}

R Shriyan. Dept of Paediatrics, Vardhman Mahavir Medical College and Safdarjung Hospital, New Delhi, India

\subsection{6/archdischild-2020-rcpch.517}

Introduction Chikungunya is neonates is a rare entity with varied clinical presentation and poses a diagnostic challenge in neonates.

Methods Four neonates were studied during the period of June to September 2016, admitted to the NICU,born to symptomatic mothers and IgM serology positive. Each of the babies was enrolled after a written informed consent. In addition to a thorough clinical history and examination these babies underwent a sepsis screen, blood culture, Chikungunya IgM ELISA and CSF examination.

Results

\begin{tabular}{|c|c|c|c|c|}
\hline Profile & Case 1 & Case 2 & Case 3 & Case 4 \\
\hline $\begin{array}{l}\text { Maternal history- } \\
\text { fever, rash, athralgia }\end{array}$ & $\begin{array}{l}2 \text { days prior to } \\
\text { delivery }\end{array}$ & $\begin{array}{l}4 \text { days prior } \\
\text { to delivery }\end{array}$ & $\begin{array}{l}7 \text { days prior } \\
\text { to delivery }\end{array}$ & $\begin{array}{l}5 \text { days prior } \\
\text { to delivery }\end{array}$ \\
\hline $\begin{array}{l}\text { Maternal } \\
\text { Chikungunya } \\
\text { serology IgM } \\
\text { Signs and Symptoms }\end{array}$ & Positive & Positive & Positive & Positive \\
\hline Fever & Present & Present & Present & Present \\
\hline Skin rash & Present & Present & Present & Present \\
\hline Refusal to feed & Present & Present & Present & Present \\
\hline Apnea & Absent & Present & Absent & Present \\
\hline Seizures & Present & Present & Absent & Present \\
\hline Shock & Absent & Present & Absent & Present \\
\hline $\begin{array}{l}\text { Encephalopathy } \\
\text { Investigations }\end{array}$ & Present & Present & Absent & Present \\
\hline Sepsis screen & Negative & Negative & Negative & Negative \\
\hline CRP & Present & Present & Present & Present \\
\hline Platelet count & 30,000/cu.mm & $\begin{array}{l}1,25,000 / \mathrm{cu} . \\
\mathrm{mm}\end{array}$ & $\begin{array}{l}1,57,000 / \mathrm{cu} . \\
\mathrm{mm}\end{array}$ & $\begin{array}{l}1,00,000 / \mathrm{cu} . \\
\mathrm{mm}\end{array}$ \\
\hline CSF & Hypoglycorrhagia & Normal & Normal & Normal \\
\hline $\begin{array}{l}\text { Chikungunya serology } \\
\text { IgM }\end{array}$ & Positive & Positive & Positive & Positive \\
\hline Ventilatory support & Required ( 2 days) & $\begin{array}{l}\text { Required ( } 2 \\
\text { days) }\end{array}$ & Not required & $\begin{array}{l}\text { Required } \\
\text { (3 days) }\end{array}$ \\
\hline Outcome & Discharge & Discharge & Discharge & Discharge \\
\hline
\end{tabular}

Conclusion A strong clinical suspicion should be kept when a newborn presents with features of encephalopathy, perioral hyperpigmentation especially in endemic areas when the mother has been viremic in the pre and intrapartum period.

\section{G604(P) FIVE CASES OF LYME DISEASE PRESENTING WITHIN A SPAN OF THREE DAYS}

O Oladiran, B Rai, P Sundaram, S bandi. Paediatrics, Leicester Royal Infirmary, Leicester, UK

\subsection{6/archdischild-2020-rcpch.518}

Background Incidence of Lyme disease in UK has been estimated as 3000 per year by Public Health England, and recent observations have raised doubt about its true incidence as it is not always reported and sometimes can undergo undiagnosed in view of its presentation as flu like illness. It is caused by Borrelia, a spirochete bacteria, transmitted by the bite of infected ticks.

Case Series Case 1: A four year old boy presented on 9th days after he had multiple insect bites while out on a boat. Initially he had developed macular rashes with mild flu like symptoms which resolved spontaneously. Few of his rashes kept enlarging and became target like lesions before he visited emergency department. Examination revealed typical target lesions over left deltoid area. Systemic examination including neurological examination were normal. He was allergic to penicillin and henceforth treated with Azithromycin for 17 days. As his presentation was typical, no investigations were required.

Case 2: A seven year old boy presented to ED with six erythema migrans rash, a day after he was bitten by insects in a park. He developed rash within a day of tick bite. He was systemically well. As he gave a distinctive history of tick bite and rashes were characteristics of the Lyme disease, no investigations were required. He was treated with Azithromycin and recovered well.

Case 3: A twelve year old female presented with erythema migrans rash two days after she was being bitten by ticks in the same park as the patient in case 2. She had no headache or cardiac symptoms. She was treated with Doxycycline for 21 days (as per NICE recommendations) and she recovered well.

Case 4 and 5: Presentations were similar to case 3 with characteristics rash and responded well to treatment.

Conclusions Characteristics rash in Lyme disease showed wide range of its first notifiable change (enlargement with central clearing and appearance of target like lesions) in our cohort of cases. It ranged from as early as 24 hours up to 9 days. History is vital in arriving at initial diagnosis.

\section{G605(P) THE MISSING LINK IN PREVENTING TETANUS DEATHS IN NIGERIAN CHILDREN}

${ }^{1} \mathrm{OM}$ Awofeso, ${ }^{2} \mathrm{Y}$ Shittu, ${ }^{2} \mathrm{C}$ Akinde, ${ }^{3} \mathrm{AA}$ Roberts, ${ }^{2} \mathrm{O}$ Buchi-Njere. ${ }^{1}$ Department of Paediatrics, Lagos University Teaching Hospital, Lagos, Nigeria; ${ }^{2}$ Department of Research, The Nigerian Child Initiative, Lagos, Nigeria; ${ }^{3}$ Department of Community Health and Primary Care, College of Medicine, University of Lagos, Lagos, Nigeria

\subsection{6/archdischild-2020-rcpch.519}

Background Global evidence reports tetanus as one of the highest contributors to preventable child deaths. Despite increasing advances in medicine, Nigeria still contributes a large burden to unnecessary child deaths having failed to eradicate tetanus.

Methods A multipronged cross-sectional study aimed at identifying contributors to tetanus deaths in children in Lagos state. A 5-year retrospective hospital survey was carried in a tertiary centre to identify paediatric admissions due to tetanus, 